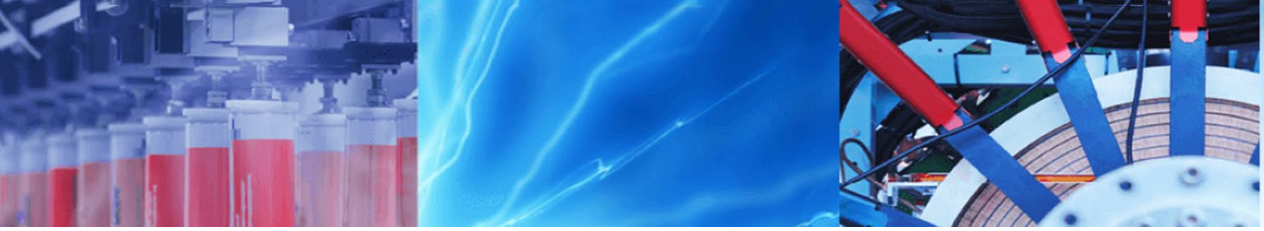

Research Article

\title{
Pelletization of pristine Pteris vittata L. pinnae powder and its application as a biosorbent of $\mathrm{Cd}(\mathrm{II})$ and $\mathrm{Cr}(\mathrm{VI})$
}

\author{
Smruthi G. Prabhu ${ }^{1} \cdot$ Govindan Srinikethan ${ }^{1} \cdot$ Smitha Hegde ${ }^{2}$
}

Received: 2 September 2019 / Accepted: 12 December 2019 / Published online: 23 December 2019

(c) Springer Nature Switzerland AG 2019

\begin{abstract}
Mobility of toxic metals, originating from natural or anthropogenic sources, from soil to groundwater is a matter of utmost concern to human health. Remediation of the contaminated groundwater is of the highest priority as groundwater is an alternate source of freshwater that is used all over the world for drinking purpose. Hence, in the present study, Pteris vittata L. is used as a simple, biodegradable and efficient biosorbent of toxic metals in its non-living and pelletized form by employing organic binders and a simple manual pellet press. The capacity of the pelletized Pteris vittata L. to sequester the metals $\mathrm{Cd}(\mathrm{II})$ and $\mathrm{Cr}(\mathrm{VI})$ from an aqueous solution is determined through the study on the effect of operating conditions, isotherm and kinetic models. The metal removal capacity of the biosorbent pelletized using corn starch as the binder is $13.51 \mathrm{mg} / \mathrm{g}$ for $\mathrm{Cd}(\mathrm{II})$ at $\mathrm{pH} 6$ and $1.66 \mathrm{mg} / \mathrm{g}$ for $\mathrm{Cr}(\mathrm{VI})$ at pH 2 as obtained from the Langmuir isotherm model. The diffusion of the metal ions into the micropores of the pellets aids its biosorption. Physical adsorption, ion exchange, covalent bonding and complexation are deduced to be few of the biosorption mechanisms involved. The findings contribute to the existing data in the biosorption technology. The novelty lies in the use of a weedy fern, Pteris vittata L., pelletized with desired structural characteristics as a potential low-cost biosorbent of toxic metals from groundwater.
\end{abstract}

Keywords Binders · Groundwater · Pellet dosage $\cdot$ Pellet stability $\cdot$ Pellet expansion · Weedy pteridophyte

\section{Introduction}

A war over a source of freshwater is not far away from reality. The scarcity of clean water is increasing day by day. Growing population and industrialization have diminished the quality and quantity of potable water. About twothirds of the global population and half the population of India are living under the conditions of water scarcity [1]. Besides surface freshwater, groundwater is an alternate source of freshwater that has continuously been subjected to the effect of human activities either directly or indirectly.
The leaching of the pollutants from the waste dump sites, pesticides of the application site soil of agricultural land and the wastewater applied to agrarian areas has led to groundwater pollution [2]. The leachates may contain organic and inorganic pollutants in them. However, the issue of grave concern today is the leaching of heavy metals into groundwater. Heavy metals have always been there, as a part of the environment, but overexploitation of resources and anthropogenic activities have increased their background concentration. Heavy metals over the past few decades have received considerable attention due to their severe effects on the living organisms $[3,4]$. Electronic supplementary material The online version of this article (https://doi.org/10.1007/s42452-019-1906-1) contains
supplementary material, which is available to authorized users.

Smitha Hegde, smitha.hegde@nitte.edu.in | 'Department of Chemical Engineering, National Institute of Technology Karnataka, Surathkal, Mangaluru, Karnataka 575 025, India. ${ }^{2}$ Division of Bioresource and Biotechnology, Nitte University Center for Science Education and Research (NUCSER), Nitte (Deemed to be University), Paneer Campus, Deralakatte, Mangaluru, Karnataka 575018 , India. 
It is vital to understand the behaviour and transport of the heavy metals in the groundwater as it is strongly dependent upon the heavy metal adsorption/ desorption capacity of the soil and the properties of the metal ions. Studies have indicated cadmium and chromium to be the highly toxic common heavy metals present in the surface soil that gradually lead to groundwater pollution [5]. Cadmium is a non-essential metal present significantly in the fertilizer-applied surface soil, in effluents of the electroplating and $\mathrm{Cd} / \mathrm{Ni}$ battery industries, and recycling sites $[6,7]$. Chromium $(\mathrm{Cr})$, on the other hand, exists as hexavalent $[\mathrm{Cr}(\mathrm{VI})]$ and trivalent $[\mathrm{Cr}(\mathrm{III})]$ chromium. $\mathrm{Cr}(\mathrm{VI})$ is the more toxic form of $\mathrm{Cr}$. $\mathrm{Cr}(\mathrm{VI})$ compared to $\mathrm{Cd}(\mathrm{II})$ has high mobility in soil/ groundwater system because of its higher solubility and lesser adsorption by aquifer materials $[5,7$, 8]. Heavy metals being highly mobile, non-biodegradable, persistent and toxic upon higher levels of exposure have to be removed from the groundwater before its consumption $[8,9]$.

Pteris vittata L., a small-medium-sized, non-edible pteridophyte with weedy potential and no seasonal limitations, was studied as a biosorbent of toxic metals in its non-living form. Untreated Pteris vittata L. pinnae tissue in its powdered form presented effective biosorption of $\mathrm{Cd}(\mathrm{II})$ and $\mathrm{Cr}(\mathrm{VI})$ with maximum removal capacities of $31.3 \mathrm{mg} / \mathrm{g}$ and $166.6 \mathrm{mg} / \mathrm{g}$ at $30^{\circ} \mathrm{C}$. Characterization studies conducted and reported in Prabhu et al. [10] proved the efficacy of the biomass as a biosorbent for $\mathrm{Cd}(\mathrm{II})$ and $\mathrm{Cr}(\mathrm{VI})$. Hence, in the present study, Pteris vittata L. powder has been immobilized to obtain a stable biosorbent by pelleting it. Batchtype sorption experiments have been conducted to screen the $\mathrm{Cd}(\mathrm{II})$ and $\mathrm{Cr}(\mathrm{VI})$ biosorption potential of the pristine Pteris vittata $\mathrm{L}$. pinnae pellets and its application to remove the toxic metals of high initial concentrations.

\section{Materials and methods}

The biomass, Pteris vittata L., grows resiliently in urban areas and is treated as an urban weed. As the biomass is abundantly available, Pteris vittata L. pinnae free of heavy metal contaminants were collected from Mangalore city and suburbs, India (coordinates: $12.87^{\circ} \mathrm{N}, 74.88^{\circ} \mathrm{E}$ ). The powdered biosorbent was prepared as per the procedure mentioned in Prabhu et al. [10].

\subsection{Preparation of Pteris vittata L. pinnae-based adsorbent pellet}

Densification of the pristine biosorbent was conducted in a manual pellet press. It includes a cylindrical die (with a diameter of $12 \mathrm{~mm}$, lengths of $34 \mathrm{~mm}$ and $13 \mathrm{~mm}$ in the presence of the pedestal) and a press $(11.88 \mathrm{~mm}$ in diameter). Pellets were prepared using various organic binders such as polyvinyl alcohol (PVA) (HiMedia Laboratories Pvt. Ltd., Nashik, India), arrowroot starch (starch from Maranta arundinacea rhizome), potato starch (starch from Solanum tuberosum tuber) and cornstarch (starch from Zea mays grains) (AksharChem ${ }^{\circledR}$, Gujarat, India) of concentrations $10 \%$ and $15 \%$. The binders were specifically chosen because of their ease in availability and unvaried quality [11]. Biodegradability is the main advantage of a biosorbent. Hence, organic binders were chosen.

Initially, organic binders and the binder concentration required to yield stable pellets were determined. The powdered biosorbent of particle size $\leq 180 \mu \mathrm{m}$ was selected for pelleting. For pelleting of the biosorbent, the powdered biosorbent was mixed thoroughly with the chosen binder (viscous) of suitable concentration at 1:1 ratio. The mixture was transferred into the pellet-press die. An approximate compaction pressure of $44.24 \mathrm{kPa}$ was applied. The procedure was repeated thrice to examine the reproducibility in pellet stability. After pelleting, the pellets were dried in an electric oven at $70^{\circ} \mathrm{C}$ for $48 \mathrm{~h}$ and stored in an airtight container until use.

\subsection{Determination of pellet stability}

\subsubsection{Water stability test of the pellets under agitation}

The stability of the pellets in water was determined by introducing the preweighed dried pellets into a conical flask containing $100 \mathrm{~mL}$ of distilled water. The pellets were continuously agitated at $150 \mathrm{rpm}$ in an electrically thermostatic reciprocating shaker (Orbitek, Scigenics Biotech, Chennai, India). From the previously established results by Prabhu et al. [10], it was anticipated that the equilibrium would be attained by $8 \mathrm{~h}$. Hence, the pellets were separated after $8 \mathrm{~h}$, dried at $60^{\circ} \mathrm{C}$ and weighed. The difference between the weight of the pellet before and after agitation gives the amount of biomass lost during the study. Pellets with a percentage stability of $80 \%$ and above were considered to be stable.

\subsubsection{Pellet stability in $\mathrm{pH}$-adjusted water}

Stability of the pellets at $\mathrm{pH} 2-7$ was determined by introducing the desired amount of pellets into $100 \mathrm{~mL}$ of $\mathrm{pH}$-adjusted water. The study was conducted under continuous agitation speed of $150 \mathrm{rpm}$. The pellets were separated after $8 \mathrm{~h}$, dried at $60^{\circ} \mathrm{C}$ and weighed. The difference between the weight of the pellet before and after agitation gives the amount of biomass lost during the study. 


\subsubsection{Relaxed density $\left(\rho_{\mathrm{r}}\right)$ and pellet expansion}

The length and diameter of ten randomly selected pellets were measured using a screw gauge immediately after pelletization. The selected pellets were measured again after a week of storage. The density calculated then is the relaxed density.

\subsection{General procedure for batch-scale experiments}

In batch-scale biosorption experiments, the effect of contact time, initial metal ion concentration and the pellet dosage on metal biosorption was established. All the glassware used was washed with detergent, immersed overnight in $10 \% \mathrm{HNO}_{3}$ and rinsed with distilled water several times to prevent cross-contamination. The biosorption of $\mathrm{Cd}(\mathrm{II})$ and $\mathrm{Cr}(\mathrm{VI})$ by the biomass pellets was conducted at $\mathrm{pH} 6$ and 2, respectively, as previously established by Prabhu et al. [10]. Unless otherwise separately mentioned, all experiments were conducted with $20 \mathrm{~g} / \mathrm{L}$ of the biosorbent dosage mixed with $100 \mathrm{~mL}$ of $100 \mathrm{mg} / \mathrm{L}$ metal solutions taken in stoppered Erlenmeyer flasks $(250 \mathrm{~mL})$ and agitated at $150 \mathrm{rpm}$ in an electrically thermostatic reciprocating shaker (Orbitek, Scigenics Biotech, Chennai, India) for $120 \mathrm{~min}$. After equilibration, the solution was filtered using Whatman No. 1 filter paper. The filtrate was refrigerated to prevent any bacterial or fungal activity until the completion of analysis. The residual metal concentration was analysed using Flame Atomic Absorption Spectrometer (GBC 932 plus, GBC Scientific Equipment Manufacturer PTY Ltd., Australia) at wavelengths of 428.9 and $228.8 \mathrm{~nm}$ for $\mathrm{Cr}(\mathrm{VI})$ and $\mathrm{Cd}(\mathrm{II})$, respectively. Controls composed of the metal solution with no biosorbent were maintained to determine whether any change in the initial metal concentration occurred.

The amount of metal uptake was calculated from the mass balance equation:

$q=\left(C_{i}-C_{f}\right) V / W$

where $V$ is the volume of the metal solution $(L)$ and $W$ is the mass of sorbent $(\mathrm{g})$.

\subsection{Preparation of synthetic metal solution}

A metal stock solution of $1000 \mathrm{mg} / \mathrm{L}$ was prepared in $500 \mathrm{~mL}$ of the standard volumetric flask by dissolving $1.4288 \mathrm{~g}$ of potassium dichromate $\left[\mathrm{K}_{2} \mathrm{Cr}_{2} \mathrm{O}_{7}\right]$ or $0.9137 \mathrm{~g}$ of cadmium chloride monohydrate $\left[\mathrm{CdCl}_{2} \mathrm{H}_{2} \mathrm{O}\right]$ in deionized water, respectively. Metal ion solutions of desired concentrations were prepared by diluting the stock solutions.

\subsection{Data evaluation}

The applicability of the kinetic models on the time course data till the attainment of equilibrium was studied using pseudo-first-order, pseudo-second-order and intraparticle diffusion models. The data acquired from the biosorption studies were subjected to equilibrium modelling to have a better understanding of biosorption. Langmuir, Freundlich, Dubinin-Radushkevich and Temkin isotherm models were used in the present study to analyse the experimental data. Further details on the models are provided in Online Resource 1.

\subsection{Statistical analysis}

Batch experiments were repeated thrice, and the mean values and error bars representing standard deviation are presented. Data gathered were subjected to one-way analysis of variance (ANOVA) at $5 \%$ level of significance, to learn whether there were any statistically significant differences between the means of the independent groups. Since the sample size was small, one-way ANOVA option, Welch's ANOVA, was applied to determine the significant difference [12]. Upon validation of all the assumptions, intergroup mean values were compared using post hoc Tukey's test. If the assumption of equal variance was violated, Games-Howell test was applied to the data for multiple comparisons. Statistical Package for the Social Sciences (SPSS) for Windows software was used for statistical analysis.

\section{Results and discussion}

It is more suitable to use immobilized biosorbent than powdered biosorbent because they reduce the clogging of the column used for water treatment and have better resistance to attrition. Also, the usage of pellets results in localization of the remediated metal, which enables easy handling and removal of the heavy metal from the contaminated sources. Hence, pelletization of the biosorbent, Pteris vittata L., was proposed to be a suitable immobilization technique over the conventional methods, as the separation and multi-cycle application of the biosorbents would be more convenient. Initial studies to assess the feasibility of the immobilization technique, the stability of the pellets and their metal uptake efficiency were conducted to understand the applicability of the biosorbent pellets. 
Table 1 Water stability study on the pellets using different binders at varied concentration

\begin{tabular}{lll}
\hline Binder & \multicolumn{2}{l}{$\begin{array}{l}\text { \% Stability of the pellets at varied } \\
\text { binder concentration }\end{array}$} \\
\cline { 2 - 3 } & $10 \%$ & $15 \%$ \\
\hline Corn starch & $83.75 \pm 0.49$ & $88.35 \pm 0.92$ \\
Potato starch & $82.90 \pm 0.57$ & $86.65 \pm 2.76$ \\
Arrow root starch & $80.65 \pm 1.20$ & $81.05 \pm 0.21$ \\
\hline
\end{tabular}

\subsection{Standardization of biosorbent pellet preparation and its quality control}

\subsubsection{Binders and pellet stability}

Table 1 displays the stability of the pellets in water excluding the pellets prepared with PVA because the pellets disintegrated upon their contact with water. Starchbased binders were proved to have differed efficiency as binders [13]. However, in the present study, statistical tests confirmed no significant difference $(p>0.05)$ in the stability of pellet offered by different binders at various concentrations.

The disintegration of the pellets prepared with polyvinyl alcohol (PVA) when put into water can be attributed to the high solubility of PVA in water at high turbulence. The stability of the pellets was affected by the binder and the treating temperature of the pellets. Temperature affects both the binder and the biomaterial. High temperature caused the melting of the components of the biomaterial. Upon cooling, solid bridges are formed between components that strengthen the pellet [14]. By the combined interaction between the moisture content and the biomass components (proteins, starch and/ or lignin) at high temperature and pressure, the proteins present in the biomass undergo plasticization/denaturation and the starch added as binders undergoes gelatinization that promotes better binding of the particles $[14,15]$. Also, the waxes and lignins present in the biomass could have undergone a glass transition at $40-50{ }^{\circ} \mathrm{C}$ and $65-75^{\circ} \mathrm{C}$, respectively, as reported by Stelte et al. [11]. The combined mechanism of glass transition/plasticization of the biomaterial components and gelatinization of starch-based binder followed by hardening could have played an essential role in binding and improving the strength of the pellets, thus yielding non-significant differences in the stability of pellets offered by different starch-based binders.

\subsubsection{Pellet stability in pH-adjusted water}

To study the applicability of the pellets at a wide range of water $\mathrm{pH}$, the pellets prepared with $15 \%$ corn starch binder were tested for stability from $\mathrm{pH} 2$ to 6 . The solution $\mathrm{pH}$ influenced the stability of the pellets. As the $\mathrm{pH}$ was increased from 2 to 6 , the stability of the pellets increased from $65.46 \pm 5.06$ to $86.53 \pm 0.87 \%$ at $\mathrm{pH} 6$ (Online Resource 2 , Fig. S1). Welch's ANOVA was conducted to compare the effect of $\mathrm{pH}$ on the stability of the pellets. The effect was significant with ${ }^{*} p<0.05$, Welch's $F(4,4.79)=12.515$. Tukey's post hoc comparisons indicated the pellet percentage stability at $\mathrm{pH} 2$ to be significantly lower $(p=0.000)$ $(M=65.46, \mathrm{SD}=5.06)$ than at $\mathrm{pH} 3(M=88.43, \mathrm{SD}=0.65)$, $4(M=86.3, \mathrm{SD}=1.01), 5(M=86.93, \mathrm{SD}=0.47)$ and 6 $(M=86.53, S D=0.87)$.

\subsubsection{Relaxed density and pellet expansion}

Table 2 presents the compressed and relaxed density of the pellets after a week's storage. A slight increase in the relaxed pellet length was observed upon storing. However, the change was insignificant $(p=0.626)$ compared to compressed pellet length. Though there was a significant difference ${ }^{*} p=0.027$ ) observed in the compressed density and relaxed density, the lower relaxed density could be attributed to the loss of moisture (wt \%) content of the pellets during the heat treatment of the pellets before storage. The pellets thus prepared were suitable to be used as a biosorbent.

During the storage of the pellets, the pellets could expand, having a substantial impact on their quality as a biosorbent. The elasticity of the fibres in the biomass causes the spring back of the pellets resulting in volume expansion and reduced density of the pellets. Si et al. [16] explain the probability of longitudinal expansion or increased length of the pellet over diametric expansion. The axial pressure applied to the biomass during pelleting is assumed to be the reason.

Our previous work [17] inferred amide $(-\mathrm{C}=\mathrm{O})$, carboxyl $(-\mathrm{COO})$ and alcohol/ester alkoxy $(-\mathrm{CO})$ to be the functional

Table 2 Relaxed density $\left(\rho_{\mathrm{r}}\right)$ and pellet expansion parameters of the pellets with cornstarch as the binder

\begin{tabular}{lc}
\hline Maximum compression density $\left(\rho_{\mathrm{m}}\right)^{\mathrm{a}, \mathrm{c}}, \mathrm{kg} / \mathrm{m}^{3}$ & $942.05 \pm 106.21$ \\
Relaxed density $\left(\rho_{\mathrm{r}}\right)^{\mathrm{b}, \mathrm{c}}, \mathrm{kg} / \mathrm{m}^{3}$ & $769.60 \pm 72.70$ \\
Length of the pellets ${ }^{\mathrm{c}}(\mathrm{mm})$ & $6.36 \pm 0.70$ \\
$\quad$ Before storage & $6.80 \pm 0.84$ \\
$\quad$ After storage & $10.74 \pm 0.57$ \\
Diameter of the pellets ${ }^{\mathrm{c}}(\mathrm{mm})$ & $10.52 \pm 0.49$ \\
$\quad$ Before storage & \\
After storage & \\
\hline${ }^{\mathrm{a}} \rho_{\mathrm{m}}$ was measured as soon as the biosorbent was pelletized \\
${ }^{\mathrm{b}} \rho_{r}$ was measured after a week of storage \\
${ }^{c} n=8$
\end{tabular}


Fig. 1 Effect of biosorbent dosage on the uptake of $\mathrm{Cd}$ (II) and $\mathrm{Cr}(\mathrm{VI})$ by the pelletized biosorbent. Conditions: initial metal concentration of $100 \mathrm{mg} / \mathrm{L}$ at $30^{\circ} \mathrm{C}$ with an agitation speed of $150 \mathrm{rpm}$. Values are expressed as mean \pm SD.

${ }^{\ddagger \neq \neq} p=0.000$ compared to $\mathrm{Cd}(\mathrm{II})$ sorption at $20 \mathrm{~g} / \mathrm{L},{ }^{\# \# \#} p=0.000$ compared to $\mathrm{Cd}$ (II) sorption at $20 \mathrm{~g} / \mathrm{L},{ }^{\dagger+} p=0.003$ compared to $\mathrm{Cr}(\mathrm{VI})$ sorption at $15 \mathrm{~g} / \mathrm{L}$

Fig. 2 Effect of biosorbent dosage on the $\mathrm{Cd}(\mathrm{II})$ and $\mathrm{Cr}(\mathrm{VI})$ sorption efficiency of the pelletized biosorbent. Conditions: initial metal concentration of $100 \mathrm{mg} / \mathrm{L}$ at $30^{\circ} \mathrm{C}$
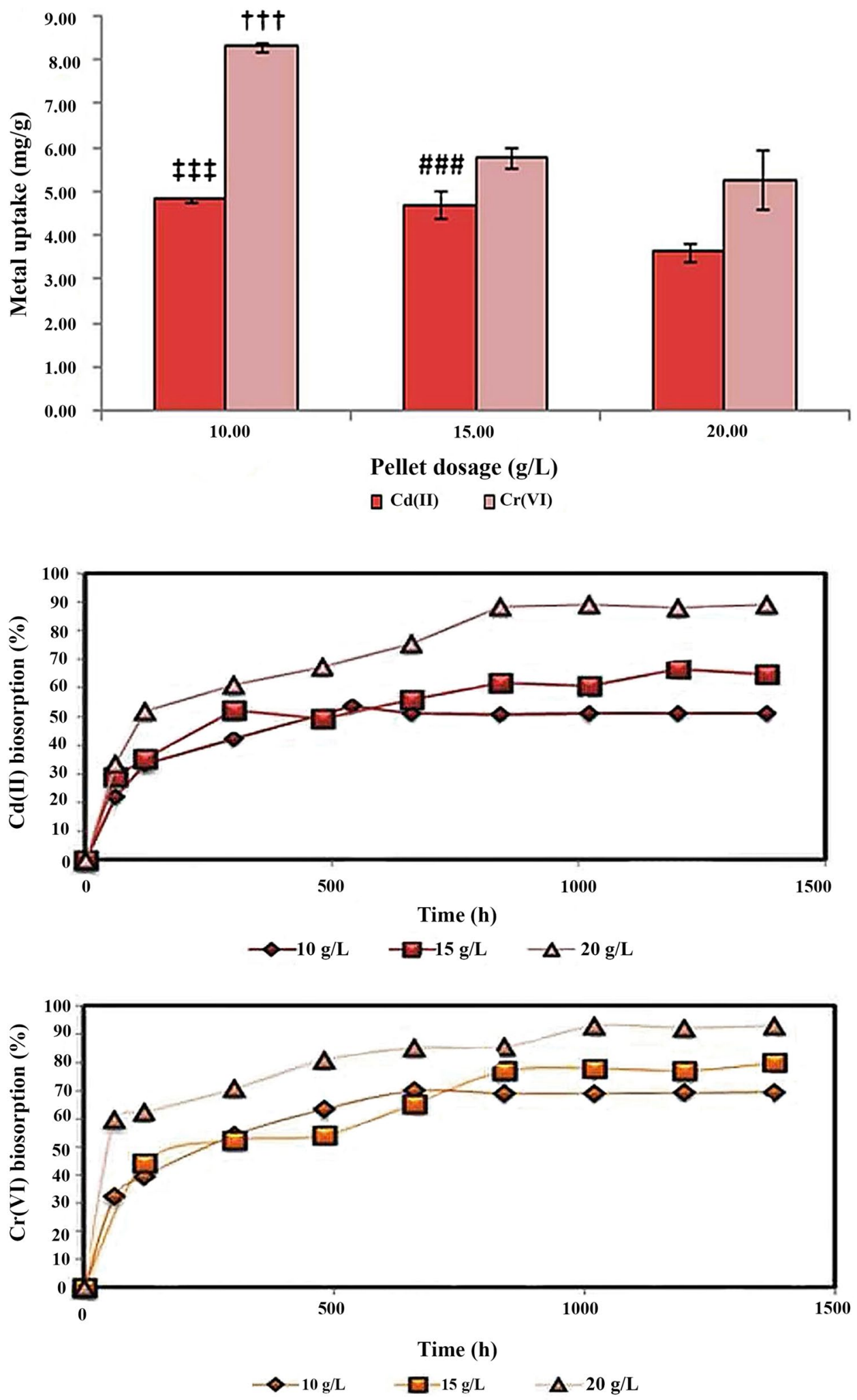
Fig. 3 Metal biosorption efficiency of the pelletized biosorbent at varied initial metal concentrations at $840 \mathrm{~min}$ and $1020 \mathrm{~min}$ for $\mathrm{Cd}(\mathrm{II})$ and $\mathrm{Cr}(\mathrm{VI})$, respectively. Means that do not share a letter are significantly different

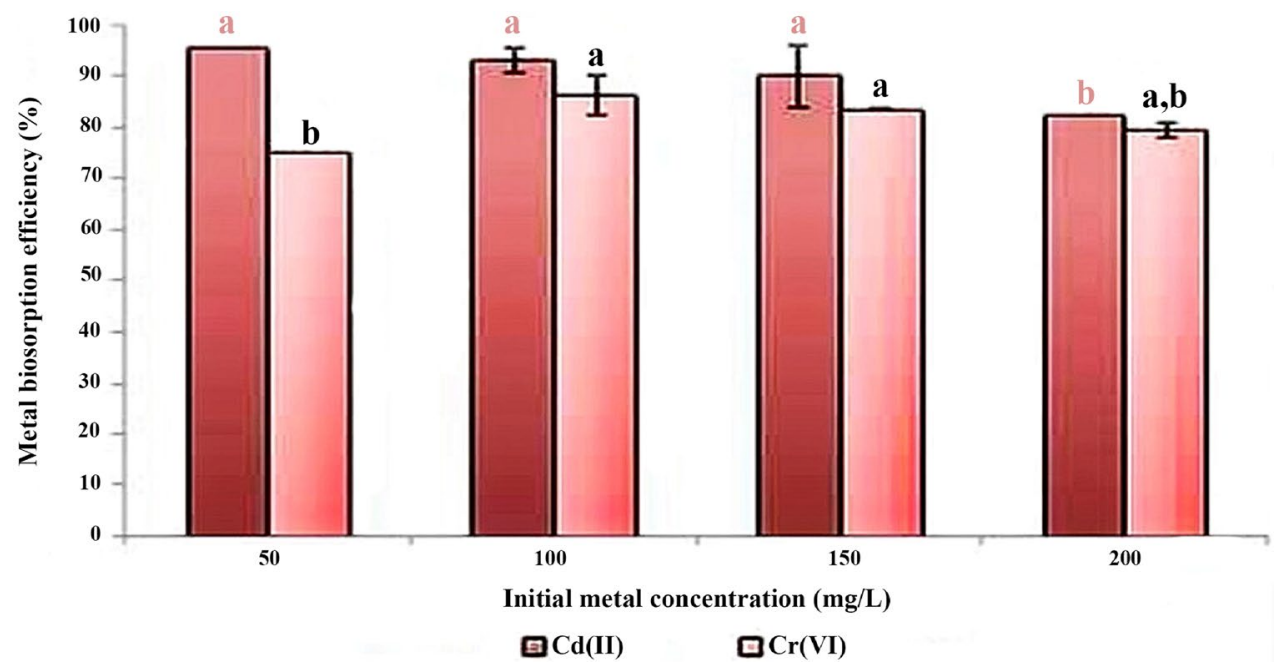

Table 3 Equilibrium uptake amount $(\mathrm{mg} / \mathrm{g})$ of $\mathrm{Cd}(\mathrm{II})$ and $\mathrm{Cr}(\mathrm{VI})$ on pelletized biosorbent at different initial metal concentrations at a biosorbent dosage of $20 \mathrm{~g} / \mathrm{L}$

\begin{tabular}{lll}
\hline $\begin{array}{l}\text { Initial metal concentration } \\
(\mathrm{mg} / \mathrm{L})\end{array}$ & $\mathrm{Cd}(\mathrm{II})$ & $\mathrm{Cr}(\mathrm{VI})$ \\
\hline 50 & $1.95 \pm 0.08$ & $1.71 \pm 0.14$ \\
100 & $3.61 \pm 2.38$ & $4.48 \pm 0.06$ \\
150 & $7.42 \pm 6.30$ & $6.81 \pm 0.22$ \\
200 & $9.19 \pm 0.00$ & $8.48 \pm 0.19$ \\
\hline
\end{tabular}

groups present in the pelletized biosorbent based upon ATR-FTIR analysis. However, amide $(-\mathrm{C}=\mathrm{O})$ and alcohol/ ester alkoxy (-CO) groups were concluded to be the active functional groups that biosorbed $\mathrm{Cd}(\mathrm{II})$ and $\mathrm{Cr}(\mathrm{VI})$ ions [10]. In the present work, to obtain maximum uptake of $\mathrm{Cd}(\mathrm{II})$ and $\mathrm{Cr}(\mathrm{VI})$ on the pelletized biosorbent, the effect of various operating conditions was ascertained.

\subsection{Determining the effect of operating conditions to obtain the maximum $\mathrm{Cd}(\mathrm{II})$ and $\mathrm{Cr}(\mathrm{VI})$ uptake by pelletized biosorbent}

The metal biosorption on pelletized biosorbent was tested using only those pellets that passed the stability tests. The effect of operating conditions on the metal biosorption was studied at a temperature of $30^{\circ} \mathrm{C}$. The controls maintained with a predetermined amount of cornstarch powder showed no changes in the initial metal concentration after the experiments, indicating the inability of the binder to remove heavy metals.
Table 4 Parameters of pseudo-second-order kinetic model for the sorption of $\mathrm{Cd}(\mathrm{II})$ and $\mathrm{Cr}(\mathrm{VI})$ on the pelletized biosorbent

\begin{tabular}{|c|c|c|c|}
\hline $\begin{array}{l}\text { Pellet dosage } \\
\text { (g/L) }\end{array}$ & $q_{e}(\mathrm{mg} / \mathrm{g})$ & $\begin{array}{l}\text { Theoretical } q_{e} \\
(\mathrm{mg} / \mathrm{g})\end{array}$ & $R^{2}$ \\
\hline \multicolumn{4}{|c|}{ Pseudo-second-order kinetic model $\left(t / q_{t}=t / q_{e}+1 / q_{e}^{2} k\right)$} \\
\hline \multicolumn{4}{|l|}{$\mathrm{Cd}(\mathrm{II})$} \\
\hline 10 & 4.82 & 5.59 & 0.953 \\
\hline 15 & 4.70 & 4.97 & 0.988 \\
\hline 20 & 3.62 & 4.13 & 0.985 \\
\hline \multicolumn{4}{|l|}{$\mathrm{Cr}(\mathrm{VI})$} \\
\hline 10 & 8.31 & 8.77 & 0.975 \\
\hline 15 & 5.76 & 6.17 & 0.973 \\
\hline 20 & 5.28 & 5.88 & 0.996 \\
\hline
\end{tabular}

\subsubsection{Effect of pellet dosage on biosorption of $\mathrm{Cd}(\mathrm{II})$ and $\mathrm{Cr}(\mathrm{VI})$}

Figure 1 displays a decrease in the equilibrium biosorption amount $(\mathrm{mg} / \mathrm{g})$ of $\mathrm{Cd}(\mathrm{II})$ and $\mathrm{Cr}(\mathrm{VI})$ on the pelletized biosorbent with an increase in the pellet dosage. Figure 2, on the other hand, shows an increase in the biosorption efficiency of the pellets at equilibrium. The uptake of $\mathrm{Cd}(\mathrm{II})$ and $\mathrm{Cr}(\mathrm{VI})$ was gradual on pelletized Pteris vittata $\mathrm{L}$ pellets. The decrease in the metal uptake with an increase in dosage is attributed to unsaturation of the binding sites through adsorption reaction. On the other hand, the higher availability of the exchangeable sites results in increased percent removal of heavy metals. The results are in agreement with the findings of Gavrilescu [18], Suguna and Kumar [19] and Tsekova et al. [20]. 
Table 5 Intraparticle diffusion constants for metal ion uptake by pelletized biosorbent at dosages of 10,15 and $20 \mathrm{~g} / \mathrm{L}$. $\mathrm{K}_{\mathrm{id} 1}$ and $\mathrm{C}_{1}$ represent the macropore and mesopore diffusion, $\mathrm{K}_{\mathrm{id} 2}$ and $\mathrm{C}_{2}$ represent the micropore diffusion stage, and $\mathrm{K}_{\mathrm{id} 3}$ and $\mathrm{C}_{3}$ represent the equilibrium

\begin{tabular}{llrr}
\hline \multicolumn{4}{l}{ Intraparticle diffusion model $\left(q_{t}=t^{0.5} k_{\text {id }}+c\right)$} \\
\hline Pellet dosage & $10 \mathrm{~g} / \mathrm{L}$ & $15 \mathrm{~g} / \mathrm{L}$ & $20 \mathrm{~g} / \mathrm{L}$ \\
\hline $\mathrm{Cd}(\mathrm{II})$ & & & \\
$K_{\text {id1 }}\left(\mathrm{mg} / \mathrm{gmin}^{1 / 2}\right)$ & 0.27 & 0.29 & 0.23 \\
$C_{1}$ & 0.18 & -0.29 & -0.49 \\
$K_{\text {id2 }}\left(\mathrm{mg} / \mathrm{gmin}^{1 / 2}\right)$ & 0.10 & 0.08 & 0.07 \\
$C_{2}$ & 2.04 & 1.96 & 1.21 \\
$K_{\text {id3 }}\left(\mathrm{mg} / \mathrm{gmin}^{1 / 2}\right)$ & 0.00 & 0.06 & 0.02 \\
$C_{3}$ & 4.82 & 2.58 & 3.14 \\
$\mathrm{Cr}(\mathrm{VI})$ & & & \\
$K_{i d 1}\left(\mathrm{mg} / \mathrm{gmin}^{1 / 2}\right)$ & 0.34 & 0.09 & 0.03 \\
$C_{1}$ & 1.25 & 3.35 & 3.42 \\
$K_{i d 2}\left(\mathrm{mg} / \mathrm{gmin}^{1 / 2}\right)$ & 0.26 & 0.10 & 0.10 \\
$C_{2}$ & 2.05 & 2.15 & 2.56 \\
$K_{i d 3}\left(\mathrm{mg} / \mathrm{gmin}^{1 / 2}\right)$ & 0.01 & 0.01 & 0.03 \\
$C_{3}$ & 8.30 & 5.37 & 4.43 \\
\hline
\end{tabular}

\subsubsection{Effect of initial metal concentration on biosorption of $\mathrm{Cd}(\mathrm{II})$ and $\mathrm{Cr}(\mathrm{VI})$ on pelletized biosorbent}

The effect of initial metal concentrations was studied from 50 to $200 \mathrm{mg} / \mathrm{L}$ with a biosorbent dosage of $20 \mathrm{~g} / \mathrm{L}$. The factor of initial metal concentration is vital to understand the sensitivity of the pelletized biosorbent to lower metal concentrations. Figure 3 displays the decrease in biosorption efficiency of $\mathrm{Cd}(\mathrm{II})$ and $\mathrm{Cr}(\mathrm{VI})$ on the pelletized biosorbent with increasing initial metal concentrations. The decrease in the biosorption efficiency of the pellet at higher concentrations of $\mathrm{Cd}(\mathrm{II})$ and $\mathrm{Cr}(\mathrm{VI})$ is associated with the saturated active sites. From Table 3 , it is observed that the equilibrium metal uptake amount of $\mathrm{Cd}(\mathrm{II})$ and $\mathrm{Cr}(\mathrm{VI})$ increases with the increase in its concentration. The pellets displayed significant $\left.{ }^{* *} p<0.005\right) \mathrm{Cr}(\mathrm{VI})$ biosorption at 100 and $150 \mathrm{mg} / \mathrm{L}$ compared to $50 \mathrm{mg} / \mathrm{L}$. The increase in equilibrium uptake amount of $\mathrm{Cd}(\mathrm{II})$ and $\mathrm{Cr}(\mathrm{VI})$ with increasing initial metal concentration is attributed to the necessary driving force provided at higher metal concentrations that helps overcome the mass transfer resistances of the molecules present between the aqueous and the solid phases.

Sağ and Aktay [21] and Pokethitiyook and Poolpak [22] in their work have linked the reduced diffusion of the metal ions in the boundary layer of the biosorbent at higher metal concentrations to the decrease in the biosorption efficiency of the pellet at higher initial metal concentrations. Malkoc and Nuhoglu [23], on the other hand, have associated the increase in metal uptake with the greater driving force provided at higher metal concentrations that help overcome the mass transfer resistance.

\subsection{Biosorption kinetic studies}

In the present study, the controlling mechanism of metal biosorption was investigated by fitting adsorption

Table 6 Isotherm model parameters applied to the biosorption of $\mathrm{Cd}(\mathrm{II})$ and $\mathrm{Cr}(\mathrm{VI})$

\begin{tabular}{|c|c|c|c|c|c|}
\hline $\mathrm{Cd}(\mathrm{II})$ & $\mathrm{Cr}(\mathrm{VI})$ & $\mathrm{Cd}(\mathrm{II})$ & $\mathrm{Cr}(\mathrm{VI})$ & $\mathrm{Cd}(\mathrm{II})$ & $\mathrm{Cr}(\mathrm{VI})$ \\
\hline \multicolumn{6}{|c|}{ Langmuir Isotherm Model $\left(C_{e} / q_{e}=1 / b Q_{o}+C_{e} / Q_{o}\right)$} \\
\hline \multicolumn{2}{|c|}{$Q_{o}(\mathrm{mg} / \mathrm{g})$} & \multicolumn{2}{|c|}{$b(\mathrm{~L} / \mathrm{mg})$} & \multicolumn{2}{|c|}{$\mathrm{R}^{2}$} \\
\hline 13.51 & 1.66 & 0.06 & 0.64 & 0.94 & 0.91 \\
\hline \multicolumn{6}{|c|}{ Freundlich Isotherm Model $\left(\log q_{e}=\log k_{f}+1 / n \log C_{e}\right)$} \\
\hline \multicolumn{2}{|c|}{$K_{f}(\mathrm{~L} / \mathrm{g})$} & \multicolumn{2}{|c|}{$1 / n$} & \multicolumn{2}{|c|}{$\mathrm{R}^{2}$} \\
\hline 1.34 & 0.0625 & 0.55 & 1.40 & 0.91 & 0.85 \\
\hline \multicolumn{6}{|c|}{ Dubinin-Radushkevich Model $\left(\ln q_{e}=\ln q_{D}-B_{D}\left[R T \ln \left(1+\frac{1}{C_{e}}\right)\right]^{2}\right)$} \\
\hline \multicolumn{2}{|c|}{$q_{D}(\mathrm{mg} / \mathrm{g})$} & \multicolumn{2}{|c|}{$B_{D}\left(\mathrm{~mol}^{2} / \mathrm{kJ}^{2}\right)$} & \multicolumn{2}{|c|}{$\mathrm{R}^{2}$} \\
\hline 9.61 & 10.84 & $0.76^{*} 10^{-5}$ & $0.17^{*} 10^{-4}$ & 1.00 & 0.91 \\
\hline \multicolumn{6}{|c|}{ Temkin Isotherm Model $\left(q_{e}=\boldsymbol{B} \ln A+B \ln C_{e}\right)$} \\
\hline \multicolumn{2}{|c|}{$A(\mathrm{~L} / \mathrm{g})$} & \multicolumn{2}{|c|}{$b(\mathrm{~J} / \mathrm{mol})$} & \multicolumn{2}{|c|}{$\mathrm{R}^{2}$} \\
\hline 0.54 & 0.20 & 697.63 & 793.18 & 0.92 & 1.0 \\
\hline
\end{tabular}


reaction models, pseudo-first-, pseudo-second-order and intraparticle diffusion models, to the experimental data. The models were accepted only when the correlation coefficient was close to unity.

A lower correlation coefficient was obtained for the pseudo-first-order kinetic model (Online Resource 3, Table S1) compared to pseudo-second-order kinetic model. Table 4 presents the parameters of pseudo-secondorder kinetic model for the sorption of $\mathrm{Cd}(\mathrm{II})$ and $\mathrm{Cr}(\mathrm{VI})$ on the pelletized biosorbent. From Table 4, it is seen that the experimental and theoretical $q_{e}$ values in pseudo-secondorder model were very close. The slight difference is due to the heterogeneous nature of the biosorbent. The low correlation coefficient obtained for the pseudo-first-order kinetic model suggests the biosorption of $\mathrm{Cd}(\mathrm{II})$ or $\mathrm{Cr}(\mathrm{VI})$ on pelletized biosorbent not to occur onto one site per ion. However, high correlation coefficients for the pseudosecond-order kinetic model indicate the rate-limiting step to be chemisorption. Ho and McKay [24] have reported the pseudo-first-order model to be applicable for an initial period only, whereas the pseudo-second-order model to be applicable for an extended period.

Intraparticle diffusion plays a crucial role in biosorption on a porous biosorbent. Hence, the kinetic data were fitted into the intraparticle diffusion model. Intraparticle diffusion model studies indicated the metal biosorption to be influenced by macro-, meso- and micropore diffusion. Table 5 shows the significance of intraparticle diffusion in determining the uptake of $\mathrm{Cd}(\mathrm{II})$ and $\mathrm{Cr}(\mathrm{VI})$ on the pelletized biosorbent at various pellet dosages. Upon comparing the $K_{i d}$ values (Table 5), it is evident that micropore diffusion is the rate-determining step as the constants, $K_{i d 2}$ (micropore diffusion constant) were lower than those for the $K_{i d 1}$ (macropore diffusion constant). Both $K_{i d 1}$ and $K_{i d 2}$ constants were in the following order: $10>15>20 \mathrm{~g} / \mathrm{L}$. Lower $K_{\text {id }}$ value represented slower diffusion process. Hence, internal diffusion of $\mathrm{Cd}(\mathrm{II})$ and $\mathrm{Cr}(\mathrm{VI})$ was fast at pellet dosage of $10 \mathrm{~g} / \mathrm{L}$ and slowest at $20 \mathrm{~g} / \mathrm{L}$, thus justifying the trend obtained for metal uptake amount at various pellet dosages.

The $K_{\text {id } 2}$ constants at all pellet dosages were the lowest for $\mathrm{Cd}$ (II). With a molecular weight of $112.41 \mathrm{~g} / \mathrm{mol}, \mathrm{Cd}$ (II) exhibited slow micropore diffusion as indicated by the lowest micropore diffusion constant $\left(K_{i d 2}\right)$ compared to $\mathrm{Cr}(\mathrm{VI})$ of molecular weight $51.99 \mathrm{~g} / \mathrm{mol}$, thus indicating the influence of the molecular weight on micropore diffusion. The boundary layer effect was higher at the micropore diffusion stage $\left(C_{2}\right)$ than at the macropore stage $\left(C_{1}\right)$ as $C_{2}>C_{1}$.

\subsection{Adsorption isotherms}

In the present study, the adsorption isotherms were determined by varying the metal ion concentrations. Langmuir, Freundlich, Dubinin-Radushkevich and Temkin isotherm models in linear forms were tested for the experimental data. Table 6 presents the parameters of the isotherm models. Langmuir isotherm with correlation coefficients of 0.936 and 0.911 was shown to be the best fit to the experimental data compared to Freundlich model. The findings indicate the biosorption of $\mathrm{Cd}(\mathrm{II})$ and $\mathrm{Cr}(\mathrm{VI})$ on pelletized biosorbent at $30^{\circ} \mathrm{C}$ to be monolayered. The maximum $\mathrm{Cd}(\mathrm{II})$ and $\mathrm{Cr}(\mathrm{VI})$ biosorption capacity $\left(Q_{o}\right)$ of the pelletized biosorbent was $13.51 \mathrm{mg} / \mathrm{g}$ and $1.66 \mathrm{mg} / \mathrm{g}$. Furthermore, the $R_{L}$ values for $\mathrm{Cd}(\mathrm{II})$ and $\mathrm{Cr}(\mathrm{VI})$ biosorption showed a favourable biosorption process.

The D-R isotherm model plot $\left(\ln q_{e}\right.$ vs $\left.\varepsilon^{2}\right)$ was directed towards chemical sorption of $\mathrm{Cd}(\mathrm{II})$ and $\mathrm{Cr}(\mathrm{VI})$ on pelletized biosorbent at $30^{\circ} \mathrm{C}$ as free energy, $E>16 \mathrm{~kJ} / \mathrm{mol}$. The mean free energy $E$ was calculated to be $256.49 \mathrm{~kJ} / \mathrm{mol}$ for Cd(II) and $170.01 \mathrm{~kJ} / \mathrm{mol}$ for $\mathrm{Cr}(\mathrm{Vl})$. The findings are in agreement with the mean free energy range given by Argun et al. [25], Cavas [26] and Sarı and Tuzen [27]. From Table 6, the value of the heat of adsorption obtained from the Temkin isotherm data signifies the uptake of $\mathrm{Cd}(\mathrm{II})$ and $\mathrm{Cr}(\mathrm{VI})$ on pelletized biosorbent to be an exothermic process.

\section{Conclusions}

The focus of the present research was to explore an efficient biosorbent for the removal of heavy metals from the contaminated groundwater for its reuse. Pteridophytes having no direct role in the food chain are treated as weeds because of their rapid reproduction through spores. With no known application, pteridophytes were the suitable candidates for biosorbents of heavy metals. Abundant availability of the pteridophyte Pteris vittata L. in the location of research made the biomaterial more efficient. The best operating conditions required for an effective uptake of heavy metals on the biosorbent were studied by conducting batch-scale experiments. Corn starch of $15 \%$ concentration helped in binding the particles of Pteris vittata L. pinnae powder through the plasticization mechanism of the binder, yielding stable pellets. The quality of the pellets was unhampered even upon storage. The pellets, when applied as a biosorbent of $\mathrm{Cd}(\mathrm{II})$ and $\mathrm{Cr}(\mathrm{VI})$ from an aqueous system, proved to be effective. At a pellet dosage of $20 \mathrm{~g} / \mathrm{L}$, the biosorption of $\mathrm{Cd}(\mathrm{II})$ and $\mathrm{Cr}(\mathrm{VI})$ occurred with maximum efficiencies of $93.62 \%$ and $86.77 \%$ at $840 \mathrm{~min}$ and $1020 \mathrm{~min}$, respectively. Langmuir isotherm model indicated the biosorption of $\mathrm{Cd}(\mathrm{II})$ and $\mathrm{Cr}(\mathrm{VI})$ on the pelletized biosorbent to be monolayered with maximum 
biosorption capacities of $13.51 \mathrm{mg} / \mathrm{g}$ and $1.66 \mathrm{mg} / \mathrm{g}$. The $\mathrm{Cr}(\mathrm{VI})$ removal capacity at the $\mathrm{pH}$ of 2 was lower and challenging compared to $\mathrm{Cd}(\mathrm{II})$ at $\mathrm{pH} 6$ due to the instability of the biosorbent pellets at the acidic $\mathrm{pH}$. However, the lower molecular weight of $\mathrm{Cr}(\mathrm{VI})$ aided its diffusion into micropores of the pellets resulting in the biosorption of $\mathrm{Cr}(\mathrm{VI})$ to a certain extent. Physical adsorption, ion exchange, covalent bonding and complexation were deduced to be few of the sorption mechanisms involved. The results obtained in the research work have contributed to the existing data in biosorption technology that can be an alternative treatment method in groundwater treatment of heavy metals. Thus, the pelletized Pteris vittata L. is a potential biosorbent form that can be used efficiently for the removal of a metal pollutant from a near-neutral aqueous system.

Acknowledgements The authors acknowledge Aishwarya Sanjeev Kumar, Bharath Goud Ediga and Uday Krishna Devara, undergrad students, Department of Chemical Engineering, National Institute of Technology Karnataka, India, for providing help during the research. The authors are thankful to National Institute of Technology Karnataka, Surathkal, Karnataka, India, for the financial assistance provided in the form of Institute Research Fellowship to Smruthi G. Prabhu.

\section{Compliance with ethical standards}

Conflict of interest The authors declare that they have no competing interests.

\section{References}

1. Mekonnen MM, Hoekstra AY (2016) Four billion people facing severe water scarcity. Sci Adv. https://doi.org/10.1126/sciad v.1500323

2. Baharudin F, Mohd Tadza MY, Mohd Imran SN, Jani J (2018) Removal of iron and manganese in groundwater using natural biosorbent. Earth Environ Sci IOP Conf Ser 140(1):1-6

3. Tchounwou PB, Yedjou CG, Patlolla AK, Sutton DJ (2012) Heavy metals toxicity and the environment. In: Luch A (ed) Molecular, clinical and environmental toxicology. Springer, New York, pp 133-164

4. Jaishankar M, Tseten T, Anbalagan N, Mathew BB, Beeregowda KN (2014) Toxicity, mechanism and health effects of some heavy metals. Interdiscip Toxicol 7(2):60-72

5. Dong D, Zhao X, Hua X, Liu J, Gao M (2009) Investigation of the potential mobility of $\mathrm{Pb}, \mathrm{Cd}$ and $\mathrm{Cr}(\mathrm{VI})$ from moderately contaminated farmland soil to groundwater in Northwest, China. J Hazard Mater 162(2-3):1261-1268

6. Kachenko AG, Singh B, Bhatia NP (2007) Heavy metal tolerance in common fern species. Aust J Bot 55(1):63-73

7. Wuana RA, Okieimen FE (2011) Heavy metals in contaminated soils: a review of sources, chemistry, risks and best available strategies for remediation. ISRN Ecol 2011:1-20

8. Ashraf A, Bibi I, Niazi NK, Ok YS, Murtaza G, Shahid M et al (2016) Chromium(VI) sorption efficiency of acid- activated banana peel over organo-montmorillonite in aqueous solutions. Int J Phytoremediation 19(7):605-613

9. Sharma A, Sachdeva S (2015) Cadmium toxicity and its phytoremediation: a review. Int J Sci Eng Res 6(9):395-405
10. Prabhu SG, Srinikethan G, Hegde S (2019) Spontaneous Cr(VI) and $\mathrm{Cd}(\mathrm{II})$ biosorption potential of native pinnae tissue of Pteris vittata L., a tropical invasive pteridophyte. Int J Phytoremediation 21(4):380-390

11. Stelte W, Sanadi AR, Shang L, Holm JK, Ahrenfeldt J, Henriksen UB (2012) Recent developments in biomass pelletization-a review. BioResources 7(3):4451-4490

12. McDonald J (2014) Handbook of biological statistics, 3rd edn. Sparky House Publishing, Baltimore

13. Ståhl M, Berghel J, Frodeson S, Granström K, Renström R (2012) Effects on pellet properties and energy use when starch is added in the wood-fuel pelletizing process. Energy Fuels 26(3):1937-1945

14. Tabil LG (1996) Binding and pelleting characteristics of Alfalfa. Dissertation, University of Saskatchewan

15. Tumuluru JS, Conner CC, Hoover AN (2016) Method to produce durable pellets at lower energy consumption using high moisture corn stover and a corn starch binder in a flat die pellet mill. J Vis Exp 112:1-13

16. Si Y, Hu J, Wang X, Yang H, Chen Y, Shao J et al (2016) Effect of carboxymethyl cellulose binder on the quality of biomass pellets. Energy Fuels 30(7):5799-5808

17. Prabhu S, Srinikethan G, Hegde S (2019) Efficient biosorption of $\mathrm{Pb}$ (II) on Pteris vittata $\mathrm{L}$. from aqueous solution using pulsed plate column technique. Sep Sci Technol. https://doi. org/10.1080/01496395.2019.1675702

18. Gavrilescu M (2004) Removal of heavy metals from the environment by biosorption. Eng Life Sci 4(3):219-232

19. Suguna M, Kumar NS (2013) Equilibrium, kinetic and thermodynamic studies on biosorption of lead(II) and cadmium(II) from aqueous solution by polypores biomass. Indian J Chem Technol 20:57-69

20. Tsekova K, Christova D, Todorova D, Ivanova S (2011) Removal of $\mathrm{Cu}(\mathrm{II}), \mathrm{Co}(\mathrm{II})$ and $\mathrm{Fe}(\mathrm{III})$ ions from ternary solution by free and entrapped in PVA-Hydrogel biomass of Penicillium cyclopium. Biotechnol Biotechnol Equip 25(Sup 1):41-46

21. Sağ Y (2001) Biosorption of heavy metals by fungal biomass and modeling of fungal biosorption: a review. Sep Purif Rev 30(1):1-48

22. Pokethitiyook P, Poolpak T (2016) Biosorption of heavy metals from aqueous solutions. In: Ansari AA, Gill SS, Gill R, Langa GR, Newman L (eds) Phytoremediation: management of environmental contaminants. Springer International Publishing, Cham, pp 113-141

23. Malkoc E, Nuhoglu Y (2007) Potential of tea factory waste for chromium $(\mathrm{VI})$ removal from aqueous solutions: thermodynamic and kinetic studies. Sep Purif Technol 54(3):291-298

24. Ho YS, McKay G (1999) Pseudo-second order model for sorption processes. Process Biochem 34(5):451-465

25. Argun ME, Dursun S, Ozdemir C, Karatas M (2007) Heavy metal adsorption by modified oak sawdust: thermodynamics and kinetics. J Hazard Mater 141(1):77-85

26. Cavas $L$ (2008) Comment on Equilibrium sorption isotherm studies of $\mathrm{Cd}(\mathrm{II}), \mathrm{Pb}$ (II) and $\mathrm{Zn}$ (II) ions detoxification from waste water using unmodified and EDTA-modified maize husk. Electron J Biotechnol 11(2):1-3

27. Sarı A, Tuzen M (2008) Biosorption of total chromium from aqueous solution by red algae (Ceramium virgatum): equilibrium, kinetic and thermodynamic studies. J Hazard Mater 160(2-3):349-355

Publisher's Note Springer Nature remains neutral with regard to jurisdictional claims in published maps and institutional affiliations. 